\title{
The first Peruvian record of Enchodus (Actinopterygii, Aulopiformes, Enchodontidae) in the Upper Cretaceous Vivian Formation
}

\author{
*Soledad Gouiric-Cavalli1, ${ }^{1,}$, Alberto L. Cione ${ }^{1,2}$, David E. Tineo ${ }^{1,3}$, Leandro M. Pérez ${ }^{1,4}$, \\ Martín Iribarne 5 , Miguel A. Allcca Torres ${ }^{6}$, Daniel G. Poiré ${ }^{1,3}$
}

\author{
${ }^{I}$ Consejo Nacional de Investigaciones Cientificas y Tecnológicas (CONICET), Godoy Cruz 2290 (C1425FQB), Ciudad Autónoma \\ de Buenos Aires, Argentina. \\ 2 División Paleontología Vertebrados, Museo de La Plata, Facultad de Ciencias Naturales y Museo, UNLP, Paseo del Bosque s/n, \\ B1900FWA, La Plata, Buenos Aires, Argentina. \\ sgouiric@fcnym.unlp.edu.ar,acione@fcnym.unlp.edu.ar \\ 3 Centro de Investigaciones Geológicas (CONICET-UNLP), Diagonal 113 No. 275, B1904DPK, La Plata, Buenos Aires, Argentina. \\ dtineo@cig.museo.unlp.edu.ar, poire@cig.museo.unlp.edu.ar \\ ${ }^{4}$ División Paleozoología Invertebrados, Museo de La Plata, FCNyM, Anexo I, B1900FWA, La Plata, Buenos Aires, Argentina. \\ pilosaperez@gmail.com \\ 5 GeoPark, Florida 981, C1005, Ciudad Autónoma de Buenos Aires, Argentina. \\ miribarne@geo-park.com \\ ${ }^{6}$ Independent Consultant \\ allccatorres@gmail.com
}

*Corresponding author: sgouiric@fcnym.unlp.edu.ar,s.gouiriccavalli@gmail.com

\begin{abstract}
We describe isolated teleostean teeth found in no association with the jaw bone. The specimens have been recovered in Late Cretaceous marine deposits of the Vivian Formation in the Peruvian Sub-Andean Region. The deposition sequence from where the teeth come is interpreted as a shallowing-upward sequence of low salinity. The fish material is identified as Enchodus aff. E. gladiolus based on the presence of a small but well-developed post-apical barb, an anterior cutting edge, the crown is symmetrical in cross-section, have a sigmoidal profile, and bears strong ridges (=striations). The Peruvian material differs from the typical E. gladiolus teeth in having a faintly serrated anterior cutting edge which is absent in most specimens referred to E. gladiolus. We also highlight that taxonomic assignments made based on isolated teeth must be taken with care. Despite scarce, the material recovered denotes that the marine units of Peru can give valuable information about the Pacific fish fauna during the Late Cretaceous.
\end{abstract}

Keywords: Fishes, Actinopterygii, Peruvian Sub-Andean Region, South America.

RESUMEN. El primer registro peruano de Enchodus (Osteichthyes, Aulopiformes, Enchodontidae) en la Formación Vivian del Cretácico Superior. Se describen dientes aislados de peces teleósteos, los que no se encontraron asociados con huesos de las quijadas Los especímenes han sido recuperados en depósitos marinos del Cretácico tardío de la Formación Vivian en la Región Subandina del Perú. La secuencia sedimentaria de donde provienen los dientes se interpreta como una secuencia somerizante de baja salinidad. El material de peces es referido como Enchodus aff. E. gladiolus con base en la presencia de una barba posapical pequeña, pero bien desarrollada, además de un borde cortante anterior; la corona es simétrica en sección transversal, con un perfil sigmoidal y fuertes crestas (=estrías). El material peruano se diferencia de los dientes típicos de E. gladiolus en tener un borde cortante anterior ligeramente aserrado que está ausente en la mayoría de los especímenes referidos a E. gladiolus. Se destaca también que las asignaciones taxonómicas realizadas a partir de dientes aislados se deben tomar con cuidado. A pesar de ser escaso, el material recuperado denota que las unidades marinas del Perú pueden brindar información valiosa sobre la fauna de peces del Pacífico durante el Cretácico Superior. 


\section{Introduction}

The Mesozoic fish record is extremely scarce in Peru, especially compared with coeval fossil bearing localities in neighboring countries of western South America such as Bolivia and Chile (e.g., Kriwet and Klug, 2012; Suárez et al., 2003; Arratia, 2015).

Enchodontidae is a marine extinct fish clade of the teleostean neopterygian order Aulopiformes (Fielitz, 2004; Nelson et al., 2016). Enchodontids were common in many marine environments during the Late Cretaceous of different continents (North America, South America, Africa, Asia, Europe, and Antarctica; e.g., Fielitz, 2004; Kriwet et al., 2006; Silva and Gallo, 2011; Holloway et al., 2017; Cione et al., 2018; Díaz-Cruz et al., 2019). The oldest record appears to be Enchodus zimapanensis from Albian-Cenomanian beds of Mexico (Fielitz and González-Rodríguez, 2010). To date, Enchodontidae consists of seven genera being Enchodus Agassiz, 1833 the most taxonomically diverse (AlvaradoOrtega et al., 2020).

The fossil record of Enchodus is abundant in rocks from the Albian-Cenomanian to Maastrichtian (e.g., Hay, 1903; Chalifa, 1996; Kriwet, 2003; Fielitz, 2004; Fielitz and González-Rodríguez, 2010; Cavin et al., 2012; Newbrey and Konishi, 2015; DíazCruz et al., 2019). Despite there are a few reports of Enchodus (and Enchodontidae) from Cenozoic rocks; they have to be reviewed and confirmed (see Arambourg, 1952 and Rana et al., 2005).

Over the years, several Enchodus nominal species were described, many of them based on isolated mandibular fragments and teeth (Goody, 1969, 1976; Chalifa, 1989, 1996; Holloway et al., 2017). Thus, the tooth-based species and the phylogenetic relationships of Enchodus species are relatively weakly supported (Fielitz, 2004).

One of the most striking features of Enchodus species is the presence of long palatine bones with a single, large tooth (=fang), and a corresponding dentary tooth near the mandibular symphysis. These large teeth and others have very good potential of preservation and are relatively diagnostic (Grandstaff and Parris, 1990). Moreover, isolated palatine, lower and upper jaw teeth and isolated fragmentary bones have been used to identify material at species level (e.g., Carbot-Chanona and Than-Marchese, 2013) and considered type material (e.g., Holloway et al., 2017). However, the definition of species based on isolated teeth and isolated skeletal elements has been questioned (Goody, 1976; Chalifa, 1996).

The aim of this study is to describe and discuss the taxonomic assignment of isolated teeth recovered in Upper Cretaceous levels of Vivian Formation in Perú, South America. Additionally, we comment about the paleogeographic distribution of the genus Enchodus.

\section{Material and methods}

\subsection{Material}

Material consist of eight teeth -none of them associated with bone- housed at the INGEMMET (Instituto Geológico, Minero y Metalúrgico), Lima, Perú.

\subsection{Methods}

Teeth were studied and photographed under a binocular microscope. Also, a Scanning Electron Microscope FEI ESEM Quanta 200 with electron source from a tungsten filament, with accelerating voltage of $200 \mathrm{~V}-30 \mathrm{kV}$ of the SeMFi-LIMF (Servicio de Microscopía Electrónica de Barrido y Microanálisis del Laboratorio de Investigaciones de Metalurgia Física "Ing. Gregorio Cusminsky", Facultad de Ingeniería, Universidad Nacional de La Plata) was used. The Energy Dispersive X-ray spectroscopy (EDAX) analysis was performed using an EDAX SDD Apollo 40 in the SEM. This equipment allows the detection of light elements of boron, with a resolution $<135 \mathrm{eV}$, with a qualitative, semiquantitative and with the possibility of quantitative analysis on chemical elements in a microanalysis using a $1 \mathrm{~mm}^{3}$ sample.

Descriptive terminology, follows mostly Ørvig (1951), Goody (1969, 1976), and Fielitz (2004). Open nomenclature is mostly according to Bengston (1988) and follows the International Code of Zoological Nomenclature.

\section{Geological setting}

The logged Río Apurucayali Section (Fig. 1 A, B) is composed by a sedimentary rocks sequence grouped in the Chonta Formation (Moran and Fyfe, 1933), Vivian Formation (Kummel, 1948), Cachiyacu Formation (Kummel, 1948), Huchpayacu Formation (Koch and Blissenbach, 1962), 


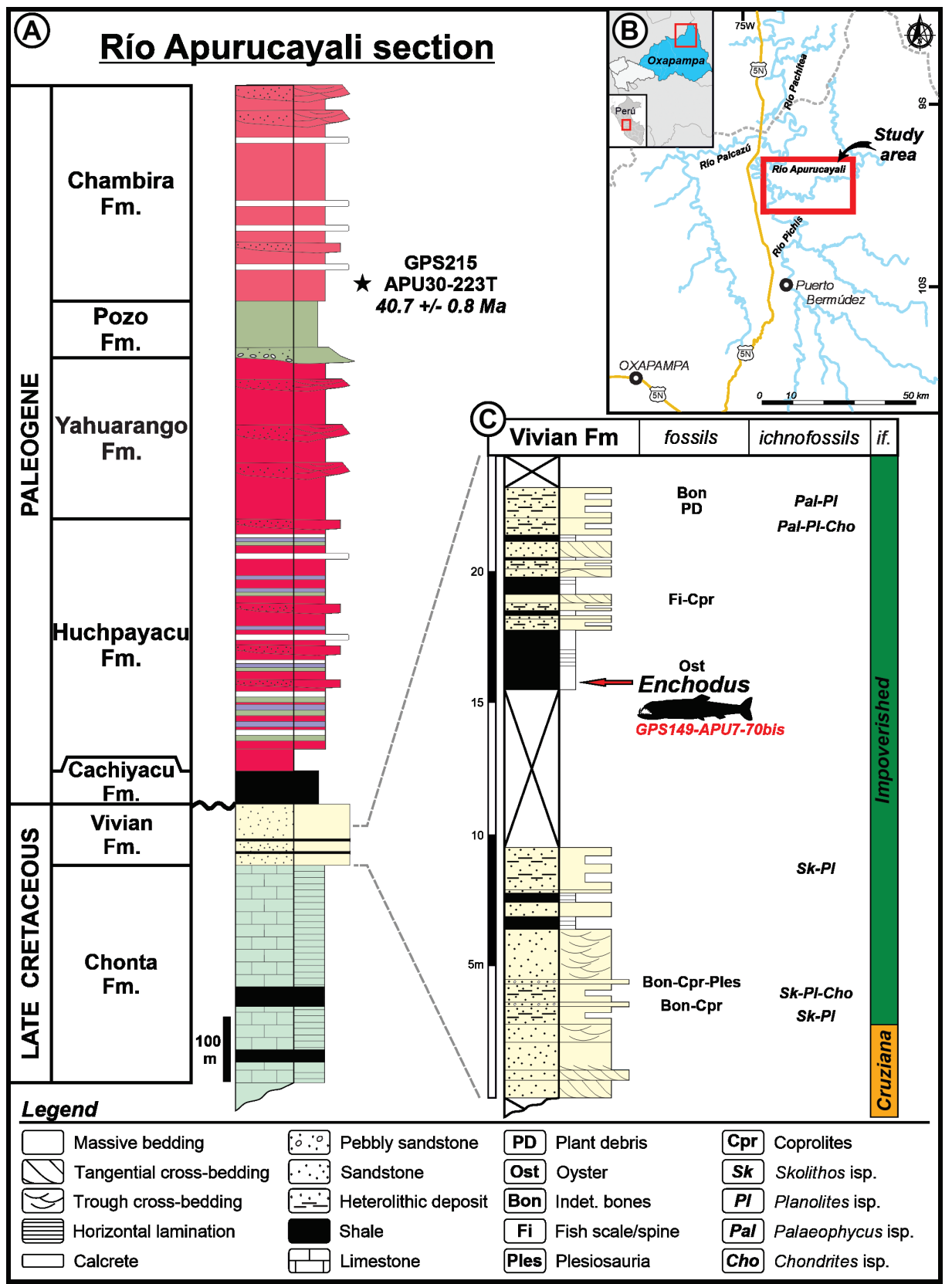

FIG. 1. A. Stratigraphic framework and general $\log$ of the Río Apurucayali Section. B. Map showing the location of Vivian Formation where Enchodus teeth were found. C. Sedimentary log of the lower part of the Vivian Formation showing the Enchodus aff. gladiolus bearing level, GPS149-APU7-70bis.

Yahuarango Formation (Kummel, 1948), Pozo Formation (Williams, 1949), and Chambira Formation (Kummel, 1946, 1948). Rocks of Chonta and Vivian formations are widely distributed in the Peruvian sub-region. Both units were assigned to the Upper Cretaceous, while the other four units above are Paleogene in age (Jaillard et al., 1995; Poiré et al., 2017). Recently, Iribarne et al. (2018) have carried 
out detrital zircon $\mathrm{U}-\mathrm{Pb}$ analyses from a tuffite level of the lower Chambira Formation in the Río Apurucayali (Fig. 1B, GPS215-APU30-223T: S10 $02^{\prime} 23^{\prime \prime}$; W74 $\left.54^{\prime} 03^{\prime \prime}\right)$ that gave a maximum depositional age of $\sim 40.7+/-0.8$ Ma. Palynological studies allowed to date the Vivian Formation from the Campanian to the Upper Maastrichtian (Elsik, 1964; Seminario and Guizado, 1973; Müller and Aliaga, 1981; Jaillard et al., 1995). In southern Peru, in the Pongo de Mainique area, detrital zircons dating indicated a more precise age of 68.5 Ma (Kennan and Pindell, 2006), which are suggesting a younger deposition age of Middle-Late Maastrichtian.

In the jungle area of Ucayali, Junín, and Pasco departments, rocks of the Vivian Formation are outcropping in isolated sections of low thickness over the margins of large river courses, as occurs in the Río Apurucayali (Fig. 1B). In this area, the logged section of the Vivian Formation (Fig. 1C) is approximately $100 \mathrm{~m}$ thick. Its general strike direction is NNE-SSW dipping up to 10 degrees west. The lower part of the Vivian Formation is characterized by fine, very well-sorted, white, quartzose arenites named "White-sugar Vivian" that become red quartzites, with reddish pelitic levels, to their upper part named as "Red Vivian". In the lower part of the Vivian Formation in the Apurucayali River profile (Fig. 1C), eight sedimentary facies have been identified, which are represented by sandy, heterolithic, and shale facies (Fig. 1C). The main psammitic facies consist of whitish, pebbly-sandstones, massive (SGm) and tangential crossbedding (SGta), and whitish sandstone, with trough crossbedding (St) tangential crossbedding (Sta), hummocky cross-stratification (Shcs) and massive sandstone ( $\mathrm{Sm}$ ). The heterolithic deposits are composed of normal heterolithic facies $(\mathrm{Ht})$ and very sand-rich heterolithic facies (Htvs). The fine, dark gray to black, shales, facies are laminated $(\mathrm{Fl})$ or massive (Fm) (Poiré et al., 2016).

Paleontological content in the lower part of the Vivian Formation at Río Apurucayali section (Fig. 1C) comprises some remains of isolated invertebrates (mollusks), vertebrate remains (fishes, reptiles: cf. Plesiosauria, coprolites) and some plant debris and carbonaceous material (Poiré et al., 2016). Trace fossils are represented by the ichnogenera Palaeophycus, Skolithos, and Chondrites, which are distributed as ichnofacies of Cruziana in its lower part and Cruziana-Skolithos Impoverished ichnofacies in its middle and upper part. The former is poorly developed, has centimeter-size diameter traces and a low bioturbation index $(\mathrm{BI}=1$ to 2$)$. On the other hand, these same ichnogenera in the Impoverished ichnofacies are well-developed but present smaller sizes (millimeters) and a high degree of bioturbation ( $\mathrm{BI}=4$ to 6) (Poiré et al., 2016).

In general, the sedimentary rocks of the Vivian Formation have been considered as the product of a deposition in marine littoral (Jaillard et al., 1995), distal fluvial (Rodríguez et al., 2017), and fluvialestuarine or fluvial-deltaic environments (Navarro, 2005). In this sense, although the presence of fossil traces of the Cruziana-Skolithos ichnofacies, very common in this unit, indicates a shallow marine environment, it is not present in the fossil level (lag), where the impoverished ichnofacies indicates deposition of sediments in brackish waters typical of an estuary (or a tide-dominated delta) (Poiré et al., 2016). It should be noted that the former is from normal salinity marine waters and pass to the same fossil but tiny traces, typical of an impoverished brackish water ichnofacies (Howard and Frey, 1975).

\section{Systematic Paleontology}

\section{Infraclass Teleostei sensu Arratia, 2013 Order Aulopiformes Rosen, 1973 \\ Family Enchodontidae Woodward, 1901 Genus Enchodus Agassiz, 1835}

Type species: Esox lewesiensis Mantell, 1822 pl., XIV, figs. 1-8; Sussex, UK, Turonian.

Cimolichthys gladiolus Cope, 1872 p. 353.

Enchodus gladiolus (Cope, 1872) in Goody 1976: 103-104 pl. 1, figs.11-12, pl.3, fig.3.

\section{Enchodus aff. Enchodus gladiolus}

Figure 2

Referred Material: A batch of eight teeth -none of them associated with bone- under the collection number CPI 7029 a-h (INGEMMET).

Geographic and stratigraphic occurrence: Site GPS GPS149-APU7-70bis (S0958'44"; W7449'19"), in the east or the Sub-Andean region in the Río Apurucayali, Pasco Department, Perú; shallowingupward sequence with low salinity facies of Late Cretaceous Vivian Formation. 


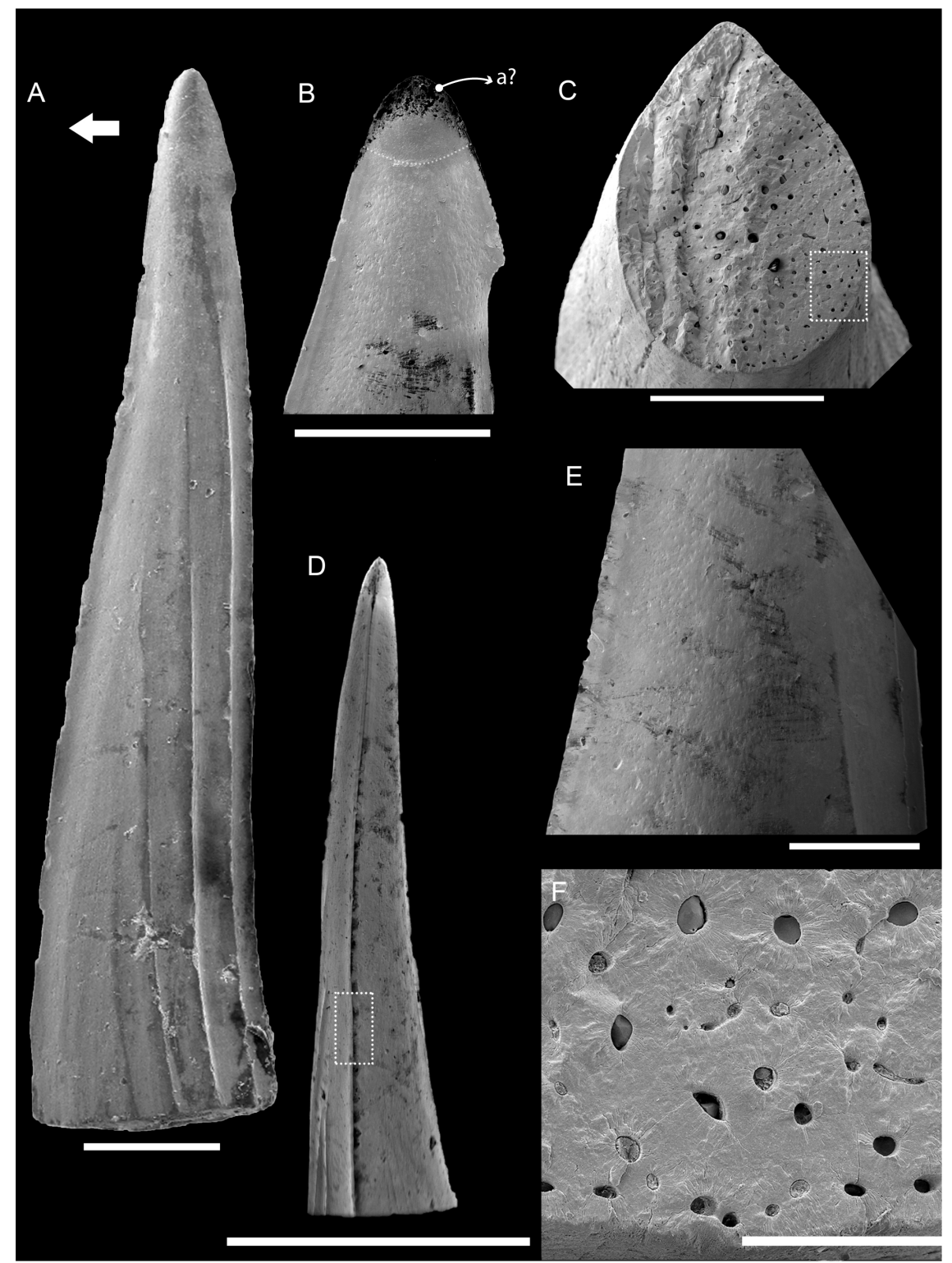

FIG. 2. Enchodus aff. gladiolus (CPI 7029a, b). A. CPI 7029a, photograph of the palatine tooth. B. CPI 7029a, detail of the apical barb, the dotted line shows the limit of the apical cap. C. CPI 7029b, cross section to show the pulp cavity and the profile. D. CPI 7029a, serration on the anterior margin of the tooth. E. CPI 7029a, anterior margin of the tooth to show the keel. F. CPI 7029b, pulp cavity showing the dentine trabeculae and denteons. Abbreviations: a?, acrodine. Scale bar: A-C: $1 \mathrm{~mm}$; D: 3 mm; E: 500 ųm; F: 200 ųm.

\subsection{Description}

The material consists of eight fang-like, small teeth. Few teeth are complete but some are incompletely preserved. Despite no teeth were connected to bone, CPI 7029a (Fig. 2A) greatly agrees in morphology with palatine fang-like teeth. CPI 7029a is about $8 \mathrm{~mm}$ long and $2 \mathrm{~mm}$ antero-posteriorly wide (measured at the tooth base). The tooth is distally compressed and slightly sigmoidal with an anterior cutting edge and a small posterior post-apical barb (Fig. 2A-B). The acrodine cap of the apical barb seems to be delimited 
by a faint outline (Fig. 2B). Since the acrodine cap shows different gray tonalities, it could be possible that the enameloid was restricted to the tip of the cap (Fig. 2B). However, a detailed histological study is necessary to allow accurate identification of the tissues. The teeth shaft has several -at least twelve- very well-developed longitudinal and undivided ridges or folds (=striations; Fig. 2A). The anterior margin of the teeth bears a slightly wavy and well-developed keel (Fig. 2A, D). In cross section, teeth are compressed near the tip and symmetrical and drop-like more basally (Fig. 2C). The anterior margin has a faint irregular serration that is only observed under SEM (Fig. 2 D-E). A natural fracture in one tooth (CPI $7029 b$ ) shows that the pulp cavity at this height is filled with osteodentine (sensu Ørvig, 1951; Fig. 2F). The complex structure is interpreted as dentine trabeculae and denteons formed around vascular canals. Radiating tubules arise from these canals (Fig. 2F). The enameloid is not clearly distinguished in the natural section but it should be located distally to the parallel series of denteons (Fig. 2F).

\subsection{Taxonomic remarks}

Enchodus is the genus of the family with more nominal species, longest stratigraphic range, and widest geographical distribution (see above). The teeth described herein resemble those of Enchodus gladiolus (Cope, 1872) in size and because they are symmetrical in cross section, have strong basoapical ridges or folds (=striations), a sigmoidal curvature of crown, an anterior cutting edge, and a small but well-developed post apical barb. Moreover, a phylogenetic analysis recently published (DíazCruz et al., 2019, fig. 7), shows that the sigmoid dermopalatine tooth is a synapomorphy of a clade gathering the species: E. gladiolus, E. dirus, the "Enchodus" from Gavdos (Cavin et al., 2012), and E. tineidae (Holloway et al., 2017). Noteworthy, "among these species the dermopalatine tooth of E. gladiolus shows a peculiar condition, a terminal wing or barb in the posterior end of its tip" (AlvaradoOrtega et al., 2020, p. 12).

Teeth from Peru greatly resemble those identified as palatine teeth of Enchodus cf. E. gladiolus (Cenomanian from Nebraska; Jansen et al. 2012); Enchodus gladiolus (Turonian of Nebraska; Ouroumova et al., 2016), Enchodus gladiolus (Maastrichtian of South Dakota; Becker et al., 2010), and Enchodus sp. (Campanian of Chiapas; AlvaradoOrtega et al., 2020).

Notwithstanding that Cope (1872, p. 353) mentioned that the barb was absent in the holotype (only specimen known to him and lost), Goody (1976, p.103), based on more complete materials, did a detailed review and assigned the species of Cope (1872) to the genus Enchodus mentioning the presence of a posterior apical barb. Since then the post-apical barb was described as commonly present in the species (e.g., Becker et al., 2010; Shimada et al., 2006).

The Peruvian teeth differ from most of North American E. gladiolus in the presence of a faintly serrated anterior cutting edge. For this and because of the scarce material (isolated teeth) available for study we decided to refer them as Enchodus aff. E. gladiolus. Recently, Carbot-Chanona and Than-Marchese (2013, p.11, fig. 2Q-T), assigned an isolated palatine tooth from the Maastrichtian of the Ocozocoautla Formation (Mexico) to Enchodus gladiolus. Notably, the tooth illustrated has an even more heavily serrated anterior margin than the Peruvian teeth reported herein. We agree with previous authors (see above) in that taxonomic assignment of isolated teeth needs to be taken carefully, and more and better-preserved material is always desirable to allow an accurate assignment. Considering that some specimens, such as those described here, show characters that are not typical of one species, the specimens must be tentatively referred to specific level. We decided to refer the Peruvian specimens as Enchodus aff. E. gladiolus denoting that probably belongs to a new species but the available material does not allow a better assignation.

\subsection{Remarks on lifestyle}

According to the morphology of the skull and due to the mouth gape, it has been postulated that Enchodus was a predator occupying a middle position in the food chain (Fielitz, 2004). Quite probably, Enchodus feeded on cephalopods and small fishes (Grandstaff and Parris, 1990) and was consumed by bigger teleosts (e.g., Cavin, 1999), sharks, and even plesiosaurs (Cicimurri and Everhart, 2001).

The genus Enchodus clusters medium-sized, predatory fishes. The largest forms might be epipelagic but most of Enchodus species seem to have been shallow-dwelling fishes inhabiting marine shelf 
or coastal waters (i.e., above $200 \mathrm{~m}$ ). Today, shelf and coastal waters have the greatest marine fish diversity and a high productivity; moreover, they are biogeographically distinct from the adjacent high seas and deep benthic environments (e.g., Spalding et al., 2007).

\subsection{Preservational remarks}

The specimens here described were found in the shallowing-upward facies of psamites that pass to a mixed composition in the lower portion of the
Vivian Formation. This shallowing-upward sequence combines the features of the low salinity proximal environment.

The facies seem to have allowed the mineralogical preservation of the crystalline material that composes the teeth. This is confirmed by the analysis of major chemical elements carried out at the tooth crown surface (Fig. 3A) and tooth pulp cavity (Fig. 3B).

The EDX-spectrum of the tooth crown surface results in an almost negligible presence of $\mathrm{C}$ indicating the absence or poor representation of $\mathrm{CaCO}_{3}$. We interpret that there was a little fossil-
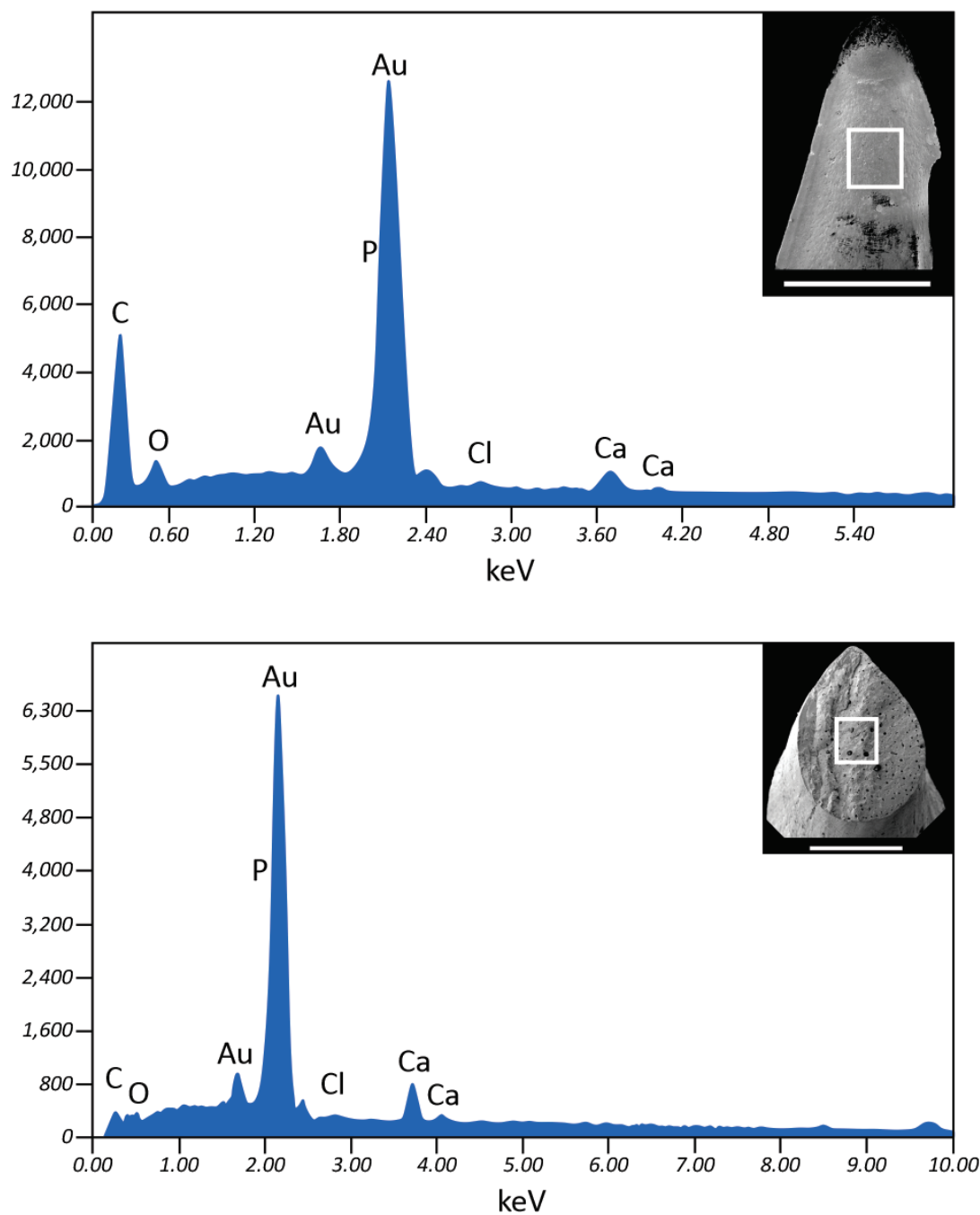

FIG. 3. Enchodus aff. gladiolus EDX-spectra. A. Chemical composition in the crown tooth surface, where a clear presence of C and $\mathrm{O}$ together with $\mathrm{P}, \mathrm{Cl}$ and $\mathrm{Ca}$ is observed. B. Chemical composition of the pulp cavity, where the presence of $\mathrm{C}$ and $\mathrm{O}$ is negligible compared to A. 
diagenetic alteration of the teeth with respect to the bearing sediments. Moreover, the EDX-spectrum of the tooth crown surface shows three main peaks -phosphorus, carbon, and oxygen- with minor peaks of calcium and chlorine. Those elements are the constituent of Calcite $\left[\mathrm{CaCo}_{3}\right]$ and Hydroxyapatite $\left[\mathrm{Ca}_{10}\left(\mathrm{PO}_{4}\right) 6(\mathrm{OH})_{2}\right]$ being the hydroxyapatite the major mineral component of teeth and bones (Carter, 1990). Likewise, the spectrum of the external surface part of the tooth would be reflecting a higher content of $\mathrm{C}$ from the carrier rock (black massive mudstone), see figure $3 \mathrm{~A}-\mathrm{B}$.

We conclude that the crystallinity of the dental material without an obvious alteration and the presence of Carbon in the apical surface of the tooth would indicate a fossil-diagenetic process that left an imprint on the phosphate material. Without an obvious replacement, the presence of elements that make up the carbonate fossil would be indicative of a protective nature of the fossil-bearing sedimentary level.

\subsection{Comments on the fossil record of Enchodus gladiolus}

Enchodus gladiolus ranges from the Cenomanian to Maastrichtian. Most of the reports come from the Western Interior Seaway of North America. The lost type material (Cope, 1872) came from the Niobrara Formation (Coniacian-Santonian of Kansas; Goody, 1976). The oldest reports are Cenomanian (e.g., Cumbaa et al., 2010; Nagrodski et al., 2012; Gallardo et al., 2013; Jansen et al., 2012). Other records are Turonian (Nebraska; Ouroumova et al., 2016) and Maastrichtian (Dakota; Becker et al., 2010). In the southern part of North America, the species was reported from the Maastrichtian of Chiapas, Mexico (Carbot-Chanona and Than-Marchese, 2013). In extracontinental areas, two fragmentary teeth assigned to Enchodus cf. gladiolus were found in Cenomanian beds of Nigeria (Vullo and Courville, 2014). However, the material is too fragmentary and should be compared with teeth of African species (see Arambourg, 1952). Teeth resembling E. gladiolus were also reported from the Campanian of Sweden (Bazzi et al., 2015). However, those teeth do not have the postapical barb and the ridges are extremely faint (see Bazzi et al., 2015, fig 5C). Bogan and Agnolin (2010, p. 185) identified one tooth from a marine Atlantic encroachment of Maastrichtian age in northern Patagonia as "Enchodus gladiolus type" sensu Goody, 1976 aff. E. gladiolus Cope, 1872”. However, the tooth figured by Bogan and Agnolin (2010, fig. 6E-F) lacks typical characters such as welldeveloped ridges or folds (=striations), it is highly compressed, and it is not sigmoidal. Consequently, we consider that all the previous reports of Enchodus gladiolus outside North America are tenuous and must be reviewed when more and better-preserved material became available.

\section{Paleobiogeography}

Due to the N-S development of the epicontinental sea during the Late Cretaceous, the latitudinal distribution of the Enchodus species was very extended -reaching Antarctica- (e.g., Cione et al., 2018; Fig. 4). This might be related with the higher average sea temperature and lower latitudinal gradient of temperature during the Late Cretaceous (Cavin et al., 2012). Also, the widening of the Northern South Atlantic Ocean during the beginning of the Late Cretaceous improved the water circulation allowing the expansion of the enchodontids distribution (Silva and Gallo, 2016).

In South America, materials referred to the genus Enchodus have been reported in the Turonian and Maastrichtian of Brazil (Cope, 1886; Woodward, 1907; Oliveira and Silva Santos, 1950; Rebouças and Silva Santos, 1956; Silva, 2007; Silva Santos and Salgado, 1969; Gallo et al., 2006). The South American Maastrichtian record also comprises an isolated mention in Chile (Quiriquina Formation; Suárez, 2001; Suárez et al., 2003), a figuration of a tooth (El Molino Formation of Bolivia; Gayet et al., 1993), and a formal description in Argentina (Jagüel Formation in Río Negro; Bogan and Agnolin, 2010). However, as was pointed out above for E. gladiolus, many of these records need to be reviewed carefully and are in need of more and better-preserved specimens. Isolated teeth of Enchodus were recorded in the Campanian-Maastricthian of Antarctica (Kriwet et al., 2006; Cione et al., 2018).

During the Late Cretaceous the radiation of Enchodus occurred in the United States -comprising part of the Western Interior Seaway and even New Jersey- from where four species have been reported (i.e., E. gladiolus, E. shumardi Leidy, 1856, E. petrosus Cope 1874, and E. dirus Leidy, 1857, see Goody, 1976 and Cavin 2008). However, in relation to the recent 


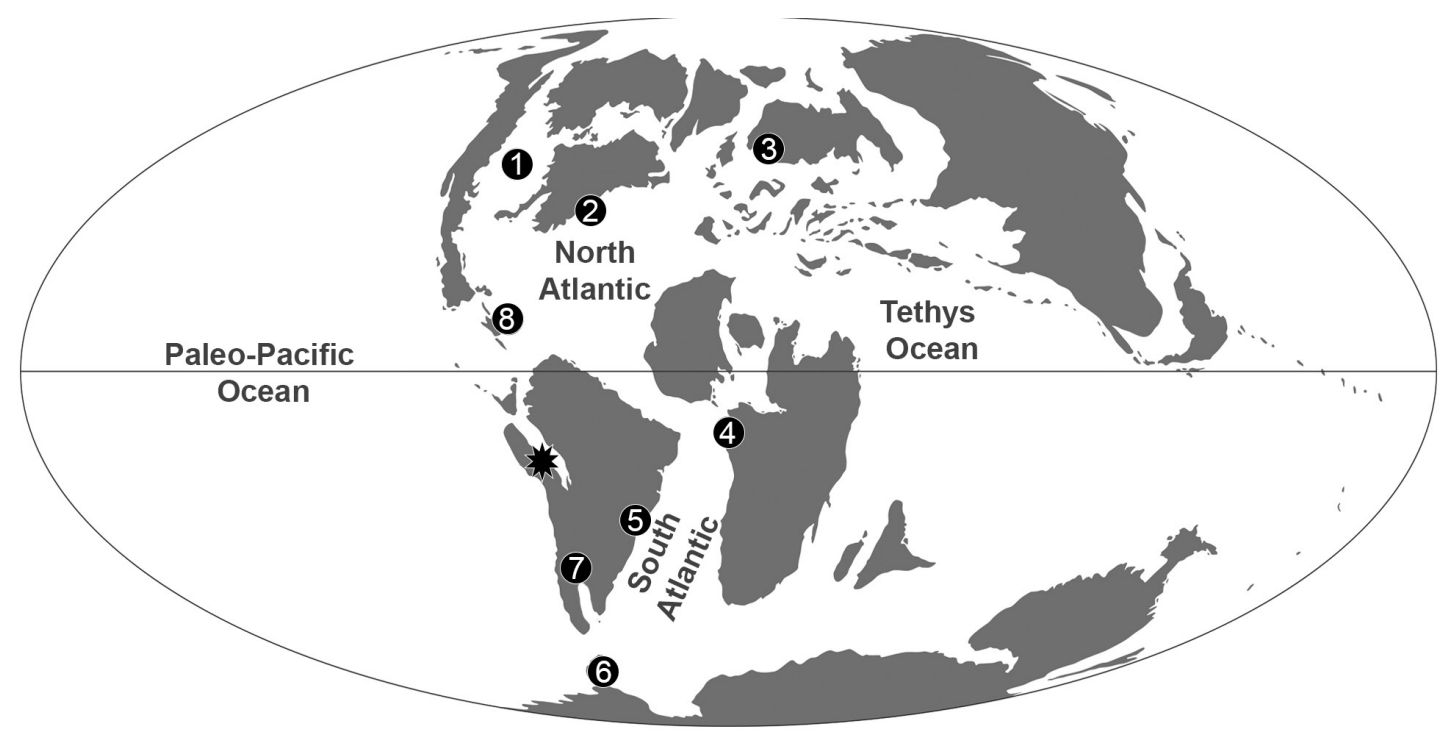

FIG. 4. Simplified paleobiogeographic distribution of the genus Enchodus during the Late Cretaceous (modified from Scotese, C.R. PaleoMap Project. http://www.scotese.com/Default.htm, accessed on May 2020). 1. Western Interior Seaway (Senonian- Maastrichtian). 2. New Jersey (Maastrichtian). 3. Sweden (Campanian). 4. Nigeria (Cenomanian). 5. Brazil (Turonian-Maastrichtian). 6. Antarctica (Campanian-Maastrichtian). 7. Argentina (Maastrichtian). 8. Mexico (Albian-Maastrichtian). The star points the (Campanian-Maastrichtian) record from Peru.

information (Alvarado-Ortega et al., 2009; Fielitz and González-Rodríguez, 2010; Díaz-Cruz et al., 2016, 2019), the radiation of Enchodus could have occurred outside the United States, including the present territory of Mexico. Although, as was mentioned by Díaz-Cruz et al. (2019), the biogeographical history of Enchodontidae is difficult to establish due to the short life span and wide inhabit region (the whole Tethyan Sea) of most of the genera.

The evidence highlights that -particularly- the Western portion of the Tethys Sea was crucial for the evolution of the Enchodontidae (see Díaz-Cruz et al., 2019). Most of the Enchodus species are restricted to epicontinental seas of temperate to tropical waters.

The report from Peru might correspond to the connections of shelf areas of the western part of South America with those of North America during the Late Cretaceous. Finally, the few Cenozoic reports of enchodontids need to be confirmed (e.g., Arambourg, 1952 mentioned but neither figured nor described rare and very small isolated teeth of E. elegans from Paleocene beds of Morocco; Rana et al., 2005 identified a tooth from the Eocene of India as Enchodus sp. However, it does not show clear diagnostic features). Thus, enchodontids seems to became extinct at the $\mathrm{K} / \mathrm{Pg}$ extinction event and apparently, no other osteichthyan occupied immediately the ecospace in shelf areas.

\section{Acknowledgments}

We owe our gratitude to the Ashaninka community of Puerto Leticia for welcoming us in the Apurucayali River. Partial funding was provided by the Consejo Nacional de Investigaciones Científicas y Tecnológicas, and the Agencia Nacional de Promoción Científica y Tecnológica through the PICT 2015-0253 to SG, Argentina. We also thank the scanning electron microscopy and microanalysis service (SeMFi-LIMF), and the Facultad de Ingeniería, Universidad Nacional de La Plata. We thank the reviewers G. Arratia, P. Brito, J. Alvarado-Ortega, and Ch. Fielitz as well as the editor, W. Vivallo for their useful suggestions and comments.

\section{References}

Agassiz, L. 1833-1843. Recherches sur les poissons fossiles (5 volumes). Imprimerie de Petitpierre: $1420 \mathrm{p}$. Neuchâtel.

Alvarado-Ortega, J.; Ovalles-Damián, E.; Blanco-Piñón, A. 2009. The fossil fishes from the Sierra Madre Formation, Ocozocoautla, Chiapas, southern México. Palaeontologia Electronica 12 (2): 1-22. 
Alvarado-Ortega, J.; Cantalice, K.M.; Martínez-Melo, A.; García-Barrera, P.; Than-Marchese, B.A.; Díaz-Cruz, J.A.; Barrientos-Lara, J.I. 2020. Tzimol, a Campanian marine paleontological site of the Angostura Formation near Comitan, Chiapas, southeastern Mexico. Cretaceous Research 107: 104279.

Arambourg, C. 1952. Les vertébrés fossiles des gisements de phosphates (Maroc, Algérie, Tunisie). Notes et Mémoires, Service Géologique du Maroc 92: 1-372. Rabat.

Arratia, G. 2013. Morphology, taxonomy, and phylogeny of Triassic pholidophorid fishes (Actinopterygii, Teleostei). Journal of Vertebrate Paleontology 33, Supplement 1: 1-138.

Arratia, G. 2015. Los peces osteíctios fósiles de Chile y su importancia en los contextos paleobiológicos y evolutivo. Publicación Ocasional del Museo Nacional de Historia Natural 63: 35-83. Chile.

Bazzi, M.; Einarsson, E.; Kear, B.J. 2015. Late Cretaceous (Campanian) actinopterygian fishes from the Kristianstad Basin of southern Sweden. In Mesozoic Biotas of Scandinavia and its Arctic Territories (Kear, B.J.; Lindgren, J.; Hurum, J.H.; Milan, J.; Vajda, V.; editors). Geological Society of London, Special Publications 434. doi: 10.1144/SP434.

Becker, M.A.; Mallery Jr. C.S.; Chamberlain Jr., J.A. 2010. Osteichthyans from an Arkadelphia Formation-Midway Group Lag Deposit (Late Maastrichtian-Paleocene), Hot Spring county, Arkansas, U.S.A. Journal of Vertebrate Paleontology 30 (4): 1019-1036.

Bengston, P. 1988. Open nomenclature. Palaeontology 31 (1): 223-227.

Bogan, S.; Agnolin, F.L. 2010. Primera ictiofauna marina del Cretácico Superior (Formación Jagüel, Maastrichtiano) de la Provincia de Río Negro, Argentina. Papéis Avulsos de Zoología 50 (12): 175-188.

Carbot-Chanona, G.; Than-Marchese, B.A. 2013. Presencia de Enchodus (Osteichthyes: Aulopiformes: Enchodontidae) en el Maastrichthiano (Cretácico Tardío) de Chiapas, México. Paleontología Mexicana 63 (2): 8-16.

Carter, J.G. 1990. Skeletal Biomineralization: Patterns, Process and Evolutionary trends. Springer: 360 p. New York.

Cavin, L. 1999. Occurrence of a juvenile teleost, Enchodus sp., in a fish gut content from the Upper Cretaceous of Goulmima, Morocco. Special papers in Palaeontology 60: 57-72.

Cavin, L. 2008. Palaeobiogeography of Cretaceous bony fishes (Actinistia, Dipnoi, and Actinopterygii).
In Fishes and the Break-up of Pangaea (Cavin, L.; Longbottom, A.; Richter, M.; editors). Geological Society: 165-183. London.

Cavin, L.; Alexopoulos, A.; Piuz, A. 2012. Late Cretaceous (Maastrichtian) ray-finned fishes from the island of Gavdos, southern Greece, with comments on the evolutionary history of the aulopiform teleost Enchodus. Bulletin de la Société Géologique de France 183 (6): 561-572.

Chalifa, Y. 1989. New species of Enchodus (Pisces: Enchodontoidei) from the Lower Cenomanian of Ein-Yabrud. Journal of Paleontology 63 (3): 356-364.

Chalifa, Y. 1996. New species of Enchodus (Aulopiformes: Enchodontidae) from the Northern Negev, Israel, with comments on evolutionary trends in the Enchodontoidei. In Mesozoic Fishes-Systematics and Paleoecology (Arratia, G.; Viohl, G.; editors). Verlag Dr. Friedrich Pfeil: 349-367. München. Cicimurri, D.J.; Everhart, M.J. 2001. An elasmosaur with stomach contents and gastroliths from the Pierre Shale (Late Cretaceous) of Kansas. Transactions of the Kansas Academy of Sciences 104 (3): 129-143.

Cione, A.L.; Santillana, S.; Gouiric-Cavalli, S.; AcostaHospitaleche, C.; Gelfo, J.; López, G.; Reguero, M. 2018. Before and after the $\mathrm{K} / \mathrm{Pg}$ extinction in West Antarctica: New marine fish records from Marambio (Seymour) Island. Cretaceous Research 85: 250-265.

Cope, E.D. 1872. On the families of fishes of the Cretaceous Formation of Kansas. Proceedings of the American Philosophical Society 12 (86): 327-357.

Cope, E.D. 1874. Review of the vertebrata of the Cretaceous period found west of the Mississippi River. Bulletin of the United States Geological and Geographical Survey of the Territories 1 (2): 3-48.

Cope, E.D. 1886. A Contribution to the Vertebrate Paleontology of Brazil. Proceedings of the American Philosophical Society 23 (121): 1-21.

Cumbaa, S.L.; Shimada, K.; Cook, T.D. 2010. MidCenomanian vertebrate faunas of the Western Interior Seaway of North America and their evolutionary, paleobiogeographical, and paleoecological implications. Palaeogeography, Palaeoclimatology, Palaeoecology 295 (1-2): 199-214.

Díaz-Cruz, J.A.; Alvarado-Ortega, J.; Carbot-Chanona, G. 2016. The Cenomanian short snout enchodontid fishes (Aulopifomes, Enchodontidae) from Sierra Madre Formation, Chiapas, southeastern México. Cretaceous Research 61: 136-150.

Díaz-Cruz, J.A.; Alvarado-Ortega, J.; Carbot-Chanona, G. 2019. Dagon avendanoi gen. and sp. nov., an Early 
Cenomanian Enchodontidae (Aulopiformes) fish from the El Chango quarry, Chiapas, southeastern Mexico. Journal of South American Earth Sciences 91: 272-284.

Elsik, W.C. 1964. A new sporomorph genus from eastern Peru. Pollen et Spores 6 (2): 601-604.

Fielitz, C. 2004. The phylogenetic relationships of the Enchodontidae (Teleostei: Aulopiformes). In Recent Advances in the Origin and Early Radiation of Vertebrates (Arratia, G.; Wilson, M.V.H.; Cloutier, R.; editors). Verlag Dr. Friedrich Pfeil: 619-634. München.

Fielitz, C.; González-Rodríguez, K.A. 2010. A New Species of Enchodus (Aulopiformes: Enchodontidae) from the Cretaceous (Albian to Cenomanian) of Zimapán, Hidalgo, México. Journal of Vertebrate Paleontology 30 (5): 1343-1351.

Gallardo, C.; Shimada, K.; Schumacher, B.A. 2013. A new Late Cretaceous marine vertebrate assemblage from the Lincoln Limestone Member of the Greenhorn Limestone in southeastern Colorado. Transactions of the Kansas Academy of Science 115 (3-4): 107-116.

Gallo, V.; Figueiredo, F.J.; Coelho, P.M. 2006. Paleoictiofauna da Formação Atlântida, Cretáceo Superior da Bacia de Pelotas, sul do Brasil. In Paleontologia de Vertebrados: Grandes Temas e Contribuições Científicas (Gallo, V.; Brito, P.M.; Silva, H.M.A.; Figueiredo, F.J. editors). Editora Interciência: 109-126. Rio de Janeiro.

Gayet, M.; Sempere, T.; Cappetta, H.; Jaillard, E.; Lévy, A. 1993. La présence de fossiles marins dans le Crétacé terminal des Andes centrales et ses conséquences paléogéographiques. Palaeogeography, Palaeoclimatology, Palaeoecology 102: 283-319.

Goody, P.C. 1969. The relationships of certain Upper Cretaceous teleosts with special reference to the myctophoids. Bulletin of the British Museum (Natural History) of Geology, Supplement 7: 1-259.

Goody, P.C. 1976. Enchodus (Teleostei: Enchodontidae) from the Upper Cretaceous Pierre Shale of Wyoming and South Dakota with an evaluation of the North American enchodontoid species. Palaeontographica, Abteilung A 152 (4-6): 91-112.

Grandstaff, B.S.; Parris, D.C. 1990. Biostratigraphy of the fossil fish Enchodus Agassiz. Journal of Vertebrate Paleontology 10: 25A.

Hay, O.P. 1903. On a collection of Upper Cretaceous fishes from Mount Lebanon, Syria, with descriptions of four new genera and nineteen new species. Bulletin of the American Museum of Natural History 19: 395-452.

Holloway, W.L.; Claeson, K.M.; Sallam, H.M.; Sanaa El-Sayed, S.; Kora, M.; Sertich, J.J.W.; O'Connor, P. 2017. A new species of the neopterygian fish Enchodus from the Duwi Formation, Campanian, Late Cretaceous, Western Desert, central Egypt. Acta Palaeontologica Polonica 62 (3): 603-611.

Howard, J.D.; Frey, R.W. 1975. Estuaries of the Georgia coast, U.S.A. Sedimentology and biology, II, regional animal-sediment characteristics of Georgia estuaries. Senckenbergiana Maritima 7: 33-103.

Iribarne, M.; Callot, P.; Ghiglione, M.; Quevedo, C.D.; Sempere, T.; Kelly, R.; Márquez, S.; Castillo, E.; Chung, J.; Seminario, F. 2018, Stratigraphy, structural styles, and hydrocarbon potential of the Ene Basin: An exploration opportunity in the Sub-Andean fold-andthrust belt of Perú. In Petroleum basins and hydrocarbon potential of the Andes of Peru and Bolivia (Zamora, G.; McClay, K.R.; Ramos, V.A.; editors). AAPG Memoir 117: 293-318.

Jaillard, E.; Álvarez, P.; Bolaños, R.; Garrido, J.; León, M.; Miró Quesada, O.; Paz, M.; Tarazona, A. 1995. Síntesis estratigráfica del Cretáceo y Paleógeno de la cuenca Oriental del Perú. Petroperú-Orstom: 3-50 p. Quito.

Jansen, K.R.; Shimada, K.; Kirkland, J.I. 2012. Fossil fish fauna from the uppermost Graneros Shale (Upper Cretaceous: middle Cenomanian) in southeastern Nebraska. Transactions of the Kansas Academy of Science 115 (3-4): 145-152.

Kennan, L.; Pindell, J. 2006. Exploration framework atlas series: Tectonic Analysis, Ltd. 3: The Central Andes. Incorporating: Southernmost Colombia, Ecuador, Peru, Bolivia, Northern Chile and Northern Argentina. Tectonic Anaysis 3: 67 p.

Koch, E.; Blissenbach, E. 1962. Las Capas Rojas del Cretáceo superior-Terciario en la región del curso medio del río Ucayali, Oriente del Perú. Boletín de la Sociedad Geológica del Perú 39: 7-141.

Kriwet, J. 2003. Lancetfish teeth (neoteleostei, Alepisauroidei) from the Early Cretaceous of Alcaine, NE Spain. Lethaia 36: 323-332.

Kriwet, J.; Klug, S. 2012. Presence of the extinct sawfish, Onchosaurus (Neoselachii, Sclerorhynchiformes) in the Late Cretaceous of Peru with a review of the genus. Journal of South American Earth Sciences 39: 52-58.

Kriwet, J.; Lirio, J.M.; Núñez, H.J.; Puceat E.; Lécuyer, C. 2006. Late Cretaceous Antarctic fish diversity. In Cretaceous-Tertiary High-Latitude Palaeoenvironments, James Ross Basin, Antarctica (Francis, J.E.; Crame, J.A.; editors). Geological Society of London, Special Publication 258: 83-100.

Kummel, B. 1946. Estratigrafía de la región de Santa Clara. Boletín de la Sociedad Geológica del Perú 19: 133-144. 
Kummel, B. 1948. Geological reconnaissance of the Contamana region, Peru. Geological Society of America, Bulletin 59: 1217-1266.

Leidy, J. 1856. Notices of some remains of fishes discovered by Dr. John E. Evans. Proceedings of the Academy of Natural Science of Philadelphia 8: 256-257.

Leidy, J. 1857. Notices of some remains of fishes. Proceedings of the Academy of Natural Science of Philadelphia 9: 167-168.

Mantell, G.A. 1822. The fossils of the South Downs; or illustrations of the geology of Sussex. Lupton Relfe: 320 p. London.

Moran, R.; Fyfe, D. 1933. Geología de la región del Bajo de Pachitea. Boletín Oficial de la Dirección de Minas e Industrias 12 (41): 43-54. Perú.

Müller H.; Aliaga, E. 1981. Estudio bioestratigráfico del Cretáceo de la cuenca Marañón. Informe interno (Inédito), Petroperú: 57 p. Lima.

Nagrodski, M.; Shimada, K.; Schumacher B.A. 2012. Marine vertebrates from the Hartland Shale (Upper Cretaceous: Upper Cenomanian) in southeastern Colorado, USA. Cretaceous Research 37: 76-88.

Navarro, L. 2005. La Cuenca de Santiago: estilo estructural y sistemas petroleros. Tesis de Grado (Inédita), Universidad Nacional San Agustín de Arequipa: 86 p. Perú.

Nelson, J.S.; Grande, T.C.; Wilson, M.V.H. 2016. Fishes of the world (Fifth edition). Wiley and Sons, Hoboken: 707 p. New Jersey.

Newbrey, M.G.; Konishi, T. 2015. A new lizardfish (Teleostei, Aulopiformes) from the Late Cretaceous Bearpaw Formation of Alberta, Canada, with a revised diagnosis of Apateodus (Aulopiformes, Ichthyotringoidei). Journal of Vertebrate Paleontology 35 (3): e918042. doi: 10.1080/02724634.2014.918042.

Oliveira, P.E.; Silva Santos, R. 1950. Fósseis Cretáceos da Ilha da Itamacá. Anais da Academia Brasileira de Ciências 22 (1): 107-112. Rio de Janeiro.

Ørvig, T. 1951. Histologic studies of Placoderms and fossil Elasmobranchs. I. The endoskeleton, with remarks on the hard tissues of lower vertebrates in general. Arkiv för Zoologie 2 (2): 321-454.

Ouroumova, O.; Shimada, K.; Kirkland, J.I. 2016. Fossil marine vertebrates from the Blue Hill Shale Member (Middle Turonian) of the Upper Cretaceous Carlile Shale in northeastern Nebraska. Transactions of the Kansas Academy of Science 119 (2): 211-221.

Poiré, D.G.; Iribarne, M.; Allcca, M.; Pérez, L.M. 2016. Facies sedimentarias, trazas fósiles y restos de vertebrados marinos en sedimentitas estuáricas de la Formación
Vivian, Río Apurucayali, Perú. In Congreso Peruano de Geolgía, No. 18, Actas CD: 1-5. Lima.

Poiré, D.G.; Iribarne, M.; Allcca, M.; Castillo, E.; Pérez, L.M.; Callot, P.; Quevedo, C.D.; Vergani, G.D. 2017. Facies sedimentarias continentales del Paleógeno de las cuencas Ene y Pachitea, Departamentos de Ucayali y Junín, Perú. In Congreso Geológico Argentino, No. 20, Actas TU- S9: 38-43. San Miguel de Tucumán.

Rana, R.S.; Kumar, K.; Singh, H.; Rose, K.D. 2005. Palaeocene-Earliest Eocene Akli Formation, Giral Lignite Mine, Barmer District, western India. Current Science 89 (9): 1606-1613.

Rebouças, J.C.; Silva Santos, R. 1956. Fauna ictiológica do fosfato de Pernambuco. Divisão de Geologia e Mineralogia, Boletim 162: 1-36.

Rodríguez, R.; Cueva, E.; Sánchez, E.; Ojeda, D.; Fabian, C.; Giraldo, E. 2017. Geología del cuadrángulo de Rioja, Hoja 13i. Instituto Geológico, Minero y Metalúrgico, Carta Geológica Nacional, Serie A, Boletín 150: 82 p., 4 mapas escala 1:50.000.

Rosen, D.E. 1973. Interrelationships of higher euteleostean fishes. In Interrelationships of Fishes. (Greenwood P.H.; Miles R.S.; Patterson C.; editors). Zoological Journal of the Linnean Society 53: 397-513.

Seminario, F.; Guizado, J. 1973. Síntesis bioestratigráfica de la región de la Selva del Perú. In Congreso Latinoamericano de Geología, No. 2: 881-898. Caracas.

Shimada, K.; Schumacher, B.A.; Parkin, J.A.; Palermo, J.M. 2006. Fossil marine vertebrates from the lowermost Greenhorn Limestone (Upper Cretaceous: Middle Cenomanian) in southeastern Colorado. The Paleontological Society, Memoir 63: 1-45.

Silva, M.C. 2007. Os vertebrados da Bacia da Paraíba (Cretáceo Superior-Paleoceno), Nordeste do Brasil, Dissertação de Mestrado em Geociências. Universidade Federal de Pernambuco: $201 \mathrm{p}$.

Silva, H.M.S.; Gallo, V. 2011. Taxonomic review and phylogenetic analysis of Enchodontoidei (Teleostei: Aulopiformes). Annals of the Brazilian Academy of Sciences 83 (2): 483-511.

Silva, H.M.A.; Gallo, V. 2016. Distributional patterns of enchodontid fishes in the Late Cretaceous. Cretaceous Research 65: 223-231.

Silva Santos, R.; Salgado, M.S. 1969. Enchodus longipectoralis (Schaeffer) um Teleostei do Cretáceo de Sergipe. Anais da Academia Brasileira de Ciências 41 (3): 381-392. Río de Janeiro.

Spalding, M.D.; Fox, H.E.; Allen, G.R.; Davidson, N.; Ferdaña, Z.A.; Finlayson, M.; Halpern, B.J.; Jorge, M.A.; Lombana, A.; Lourie, S.A.; Martin, K.D.; McManus, 
E.; Molnar, J.; Recchia, C.A.; Robertson, J. 2007. Marine Ecoregions of the World: A Bioregionalization of Coastal and Shelf Areas. BioScience 57: 573-583.

Suárez, M.E. 2001. Fossil fish faunas from the Quiriquina Formation, Late Cretaceous (Maastrichtian) of Chile, South America. In International Meeting on Mesozoic Fishes, No. 3: p. 59. Eichstätt.

Suárez, M.; Quinzio, L.A.; Fritis, O.; Bonilla, R. 2003. Aportes al conocimiento de los vertebrados marinos de la formación Quiriquina. In Congreso Geológico Chileno No. 10, Sección temática 3: p. 7. Concepción. Vullo, R.; Courville, P. 2014. Fish remains (Elasmobranchii, Actinopterygii) from the Late Cretaceous of the Benue
Trough, Nigeria. Journal of African Earth Sciences 97: 194-206.

Williams, M.D. 1949. Depósitos terciarios continentales del valle del Alto Amazonas. Volumen Jubilar XXV Aniversario parte II. Sociedad Geológica del Perú. 5: 1-13. Lima.

Woodward, A.S. 1901. Catalogue of the Fossil Fishes in the British Museum (Natural History). Part 4. British Museum (Natural History): 636 p. London.

Woodward, A.S. 1907. Notes on some Upper Cretaceous fish remains from the provinces of Sergipe and Pernambuco, Brazil. Geological Magazine 4 (5): 193-197.

Manuscript received: May 20, 2020; revised/accepted: October 29, 2020; available online: January 29, 2021. 